Boise State University

ScholarWorks

$3-1-2016$

Responses of Female Burrowing Owls to Alterations in Clutch Size: Are Burrowing Owls Determinate or Indeterminate Egg-Layers?

Jamie L. Wade

Boise State University

James R. Belthoff

Boise State University 


\title{
RESPONSES OF FEMALE BURROWING OWLS TO ALTERATIONS IN CLUTCH SIZE: ARE BURROWING OWLS DETERMINATE OR INDETERMINATE EGG-LAYERS?
}

\author{
JAMIE L. WADE ${ }^{1}$ AND JAMES R. BELTHOFF \\ Department of Biological Sciences and Raptor Research Center, Boise State University, Boise, \\ ID 83725 U.S.A.
}

\begin{abstract}
Bird species, including raptors, can often be categorized into two groups depending upon their response to alterations in clutch size while laying. For some, clutch size is predetermined prior to the start of laying (i.e., determinate species). In contrast, the clutch size of indeterminate layers can be influenced by external factors present at the time of laying. Using field experiments, our objective was to examine the egg-laying responses of female Western Burrowing Owls (Athene cunicularia hypugaea) to manipulations of clutch size. To assess whether Burrowing Owls are determinate or indeterminate egg-layers, we altered female clutch size by removing or adding one egg during the laying period. At the time of egg removal or addition, the resident female had 1-5 of her own eggs present in her clutch. We compared the size of completed clutches of both removal and addition nests to the size of completed clutches at control nests. Mean clutch size at removal nests $(\overline{\mathrm{x}}=8.3$ eggs, $\mathrm{SE}=0.44, n=9)$ did not differ from controls $(\overline{\mathrm{x}}=8.8$ eggs, $\mathrm{SE}=0.18, n=17)$, whereas mean clutch size at addition nests $(\overline{\mathrm{x}}=10.7$ eggs, $\mathrm{SE}=0.66, n=9)$ was significantly larger than that of control nests. These findings demonstrate that female Burrowing Owls responded to the removal of an egg by laying a replacement, yet they did not curtail laying in response to the addition of an egg to their nest. Thus, female Burrowing Owls may be described as removal indeterminate and addition determinate. These results have implications for understanding aspects of Burrowing Owl nesting biology, such as selective advantage following the partial or total loss of a clutch of eggs, and they also may provide insight into how this behavior could facilitate conspecific brood parasitism or mitigate its costs in this species.
\end{abstract}

KeY WoRDS: Western Burrowing Owl; Athene cunicularia hypugaea; clutch size; determinate egg-laying; Idaho; indeterminate egg-laying; laying determinacy; reproduction.

RESPUESTAS DE LAS HEMBRAS DE ATHENE CUNICULARIA A ALTERACIONES EN EL TAMAÑO DE LA NIDADA: ¿ESTAS LECHUZAS SON PONEDORAS DETERMINADAS O INDETERMINADAS?

Resumen.-Las especies de aves, incluyendo a las rapaces, a menudo pueden ser categorizadas en dos grupos dependiendo de su respuesta a las alteraciones en el tamaño de la nidada durante la puesta de huevos. Para algunas, el tamaño de la nidada está predeterminado antes del comienzo de la puesta (i.e., especies determinadas). En contraste, el tamaño de la nidada de las especies indeterminadas puede ser influenciado por factores externos presentes en el momento de la puesta de huevos. Mediante experimentos de campo, examinamos las respuestas en la puesta de huevos de hembras de Athene cunicularia hypugaea a manipulaciones en el tamaño de la nidada. Para evaluar si A. cunicularia es ponedora de huevos determinada o indeterminada, alteramos el tamaño de la nidada de hembras adicionando o quitando un huevo durante el periodo de puesta. En el momento de la remoción o adición del huevo, la hembra residente tenía 1-5 de sus propios huevos presentes en su nidada. Comparamos el tamaño de las nidadas completadas en nidos con adición y en nidos con remoción de huevos con el tamaño de las nidadas completadas en nidos control. El tamaño promedio de la nidada en nidos con remoción de huevos $(\overline{\mathrm{x}}=8.3$ huevos, $\mathrm{EE}=0.44, n=9)$ no difirió de los nidos control $(\overline{\mathrm{x}}=8.8$ huevos, $\mathrm{EE}=0.18$, $n=17)$, mientras que el tamaño promedio de la nidada en nidos con adición de huevos $(\overline{\mathrm{x}}=10.7$ huevos, $\mathrm{EE}=0.66, n=9$ ) fue significativamente mayor que la de los nidos control. Estos hallazgos demuestran que las hembras de A. cunicularia respondieron a la remoción de un huevo con la puesta de un huevo de reemplazo, pero no limitaron la puesta en respuesta a la adición de un huevo a su nido. Por lo tanto, las hembras de A. cunicularia pueden ser descriptas como indeterminadas de remoción y

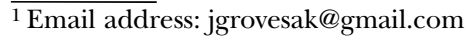


determinadas de adición. Estos resultados tienen importancia para el entendimiento de aspectos de la biología reproductiva de $A$. cunicularia, tales como la ventaja selectiva luego de la pérdida parcial o total de una nidada de huevos, y también pueden ayudar a comprender cómo este comportamiento puede facilitar el parasitismo co-específico del nido o mitigar sus costos.

[Traducción del equipo editorial]

In birds, clutch size is the most important factor in determining reproductive success in that it establishes an upper limit for the number of offspring that can be produced in any single bout of reproduction (Williams 1966, Thomson et al. 1998). The "optimal" clutch size should maximize an individual's lifetime fitness by balancing future reproductive potential with current reproductive costs. Most hypotheses regarding the evolution of an optimal clutch size originate with Lack $(1947,1954,1966)$, who hypothesized that clutch size is ultimately determined by the greatest number of offspring for which the parents can adequately provide food, assuming that individuals seek to maximize their reproductive output for each breeding attempt. This reasoning suggests that the largest clutch size that can be supported will be determined by environmental quality or the amount of food available. Offspring from oversized broods may become undernourished and experience lower survival when compared to the offspring of smaller broods. Thus, if clutch size is heritable, genotypes producing maladaptive clutch sizes will be selected against, and the final result will be that the modal clutch size will be the most productive (Klomp 1970). According to Lack's hypothesis, starvation of offspring should not only occur in oversized broods but also in those that are of average size when conditions are poor and/or parents are unable to find enough food. The practice of initiating incubation prior to clutch completion, with the result that eggs hatch asynchronously and likely giving some offspring an advantageous head start, may facilitate the adjustment of brood size to the current food supply (Lack 1954). For example, in years when food is not limited, there may be an opportunity to fledge additional young that would have likely suffered increased mortality in those years when food was scarce (Lack and Lack 1951, Ingram 1959).

Although Lack's hypotheses remain influential, his original idea has been extended to incorporate one of the fundamental tenets of life-history theory; i.e., that current reproduction comes at a cost of future reproduction (Perrins 1965, Williams 1966, Charnov and Krebs 1974). For this reason, a smaller clutch may be favored over the most productive when the short-term benefit of a greater number of fledglings is balanced by long-term costs to future reproductive success (Stearns 1976, Nur 1986, Boyce and Perrins 1987). In addition, further emphasis has been placed on the significance of individual variation in parental quality, such that each individual female is capable of adjusting her clutch size to her own unique circumstances so as to maximize her fitness (Perrins and Moss 1975, Hogstedt 1980, Pettifor et al. 1988).

Bird species, including raptors, can be placed into two groups depending upon their response to alterations in clutch size while laying. In some, clutch size is predetermined and limited by the number of large yolky follicles that develop in the ovary prior to the start of laying. This group of birds is defined as "determinate" egg-layers (Cole 1917, 1930). Neither the addition nor the removal of eggs during the laying period will affect the total number of eggs laid in determinate species.

In other bird species, the number of eggs a female is capable of producing is not predetermined and can be influenced by external factors present at the time of laying. Cole $(1917,1930)$ defined these birds as "indeterminate" egg-layers. Removal of eggs during laying delays the onset of incubation and stimulates an indeterminate female to recruit additional ovarian follicles; this extends the laying period, and females effectively replace the lost eggs. When eggs are added to the clutch of an indeterminate female, further follicular development is inhibited and/or existing follicles are resorbed, and egg-laying ceases early (Kennedy 1991, Haywood 1993, 2013).

As natural instances of egg removal and addition could occur independently (e.g., through nest predation and brood parasitism, respectively; Kennedy and Power 1990), a bird does not have to be both removal and addition indeterminate to be described as an indeterminate egg-layer. A species may be removal indeterminate and addition determinate, or vice versa. If a species of bird has the ability to adjust clutch size in either direction, then that species must be indeterminate to some degree (Holcomb 1971).

Although laying determinacy status has been examined in more than 100 avian species (Kennedy 1991, Haywood 1993, 2013), it has not been 
established in Western Burrowing Owls (Athene cunicularia hypugaea; hereafter Burrowing Owls). In his review of determinate and indeterminate laying, Kennedy (1991) described several traits that seem to be correlated with indeterminate laying. In general, species that lay relatively large clutch sizes tend to be indeterminate, whereas species that have small clutches tend to be determinate. Burrowing Owls lay large clutches of up to 14 eggs (Poulin et al. 2011), suggesting the potential for indeterminate laying in this species. Clutch size in Burrowing Owls can also vary substantially (4-14 eggs, Poulin et al. 2011), which is a characteristic that is also associated with species that lay indeterminately (Kennedy 1991).

To further understand Burrowing Owls' reproductive biology, we aimed to discover whether they are determinate or indeterminate egg-layers. To do so, we either removed or added one egg to Burrowing Owl nests during the female's normal laying period and compared the final clutch sizes of manipulated nests to final clutch sizes of unmanipulated control nests to examine egg-laying responses. If Burrowing Owls are indeed indeterminate egg-layers, we expected that females would adjust their clutch size to compensate for egg removal by laying an additional egg to replace the one that we removed. Likewise, if Burrowing Owls are indeterminate, under conditions of egg addition, we expected female Burrowing Owls to respond by considering the added egg when making their clutch size assessment and consequently laying one fewer of their own eggs (Kennedy 1991, Haywood 1993).

\section{Methods}

Study Area. Our study was conducted during 2012 2013 within the Morley Nelson Birds of Prey National Conservation Area (NCA) located in southwestern Idaho (Ada and Elmore counties), United States. The Snake River Canyon is the dominant geologic feature, flowing through $130 \mathrm{~km}$ of the southern and western portions of the NCA. The topography of the surrounding river plain above the canyon is flat to rolling, with rocky outcrops and a few isolated buttes. Once covered by expansive shrublands, burned and other highly disturbed areas are now dominated by invasive plants such as cheatgrass (Bromus tectorum), Russian thistle (Salsola kali), and tumble mustard (Sisymbrium altissimum; Hironaka et al. 1983, U.S.D.I. 1996). There are approximately 350 artificial burrows (deployed in clusters of two or three artificial burrows per nest-site location; Smith and Belthoff 2001) within the NCA available to Burrowing Owls for nesting or roosting (Belthoff and Smith 2003, Moulton et al. 2006). Nests examined in the current study were all in artificial burrows, which provided access to nest chambers for determining clutch sizes and for clutch size manipulations.

Locating Burrowing Owls. Surveillance for Burrowing Owl pairs began in mid-March and continued through mid-May in both years. We visited all existing artificial burrow sites at least twice during each breeding season to check for evidence of Burrowing Owl use. We considered a site occupied if we observed an owl repeatedly or saw signs of use (e.g., excreta, pellets, mammalian dung brought to the site by owls) at the burrow entrance. We inspected sites every 7-14 d and checked for eggs to confirm the presence of an actual nest.

Clutch Manipulation Experiments. To assess whether Burrowing Owls are determinate or indeterminate egg-layers, we took advantage of manipulations conducted as part of a larger study designed to address questions surrounding conspecific brood parasitism (CBP). We performed clutch size manipulations at 44 Burrowing Owl nests and monitored 17 un-manipulated control nests as part of that experiment (see Groves 2014). That investigation of CBP required that some of the clutch manipulations take place after the female's clutch was complete ( $n=22$ nests). Given that the goal of our current study was to examine the egg-laying response of Burrowing Owls following an increase or decrease in clutch size during laying, the only nests we included in the current analysis were those at which we manipulated clutch size during laying.

To facilitate clutch size manipulations, once we found eggs in a nest, we visited the nest weekly until the clutch was complete, and every 7-14 $\mathrm{d}$ thereafter. On the first and all subsequent visits, we marked all eggs with a small amount of indelible ink, which we used to discern new and older eggs. All eggs were handled to determine if they had been incubated. If eggs were cool to the touch and lacked noticeable shell coloration that often accumulates from incubation in Burrowing Owls, we considered them nonincubated; if the eggs felt warm, we considered them incubated. For all nests, we recorded the date and number of eggs present at each visit and whether incubation had started. To control for potential effects of human disturbance, we also established a set of control nests at which we performed 
all the same activities but did not permanently remove or add any eggs.

Timing of Manipulation. At many experimental and control nests, we were unable to determine the exact date of clutch initiation, because we minimized visits to nests to reduce disturbance. However, by backdating from a known clutch size and a putative laying interval of $1.5 \mathrm{~d}$ (Olenick 1990, Conway et al. 2012), we estimated clutch initiation date. To illustrate, if we found two eggs on our first visit to a nest, we assumed that those two eggs were laid $1.5 \mathrm{~d}$ apart. As a result, we estimated clutch initiation date to be $3 \mathrm{~d}$ prior to our visit. We approximated clutch completion date by applying the same method, but in reverse. Once we had an estimate of the date that a female laid her last egg, we then calculated the number of days that she was still laying eggs after we had manipulated the clutch. This information was useful in establishing whether the time interval from clutch manipulation to the laying of the last egg was sufficiently long for a female to be able to respond to experimental egg removal or addition. In other avian species, final clutch size is determined days prior (typically 3-5 d) to the laying of the last egg (Haftorn 1985, Beukeboom et al. 1988, Meijer 1990). To the best of our knowledge, there is no published information describing the mechanisms that regulate the timing of final clutch size determination in Burrowing Owls. Thus, for the purpose of our study, we chose to analyze only nests where we had manipulated clutch size five or more days prior to the estimated date that each female laid her last egg.

Egg Removal and Addition. To assess determinate or indeterminate laying behavior in Burrowing Owls, we performed egg removal and addition experiments as follows. At some nests, we removed one egg from a clutch and then immediately transferred it to another occupied nest site that was at a similar stage of development. We added the eggs that we had recently taken from removal nests, and placed them in the center of the clutch in addition nests. Thus, clutch size at removal nests was reduced by one egg, while clutch size at addition nests was increased by one egg. Egg-laying continued after removal/addition. When we ultimately found the same number of eggs in a given nest for two consecutive weeks, we recorded that number as the final clutch size. Furthermore, after the initial egg removal/addition, we continued to examine the eggs so we could be certain that they were being incubated and that the nest had not been abandoned. We then compared the completed clutch sizes of removal and addition nests to the completed clutch sizes of un-manipulated control nests to determine whether Burrowing Owls responded in a determinate or indeterminate manner.

Data Analysis. We performed nonparametric tests to examine the egg-laying response of female Burrowing Owls to clutch size manipulations because clutch sizes were not normally distributed. We separately compared the completed clutch sizes of removal and addition nests to the completed clutch sizes of unmanipulated controls using Wilcoxon Signed Rank tests. We used a significance level of alpha $<0.05$, and report means \pm SE. We performed all analyses using JMP Pro 11 Statistical Software (SAS Institute, Inc., Cary, NC U.S.A.).

\section{RESUlts}

Ultimately, we were able to assess final clutch size at $n=9$ removal nests, $n=9$ addition nests, and $n$ $=17$ control nests. Clutch manipulations occurred $10.4 \pm 0.7 \mathrm{~d}$ (range $6-17 \mathrm{~d}$ ) before the female laid her final egg.

Removal of an egg from Burrowing Owl nests did not cause owl pairs to abandon their nest. Instead, owls continued to lay eggs after egg removal. Not including the egg we removed, completed clutches at removal nests did not differ in size from unmanipulated control nests (Wilcoxon ranked sums: $Z=-0.77$, df $=1, P=0.442$, Fig. 1 ).

Females also continued to lay eggs in their nest following egg addition. Mean clutch size at addition nests was, however, significantly larger than clutch size in control nests (Wilcoxon ranked sums: $Z=$ 2.74, df $=1, P=0.006$, Fig. 1). For this analysis, the added egg was included in the calculation of final clutch size.

\section{DISCUSSION}

Burrowing Owls responded to the removal of an early-laid egg by producing a replacement, whereas they were unable or unwilling to respond to the early addition of an egg by curtailing their own laying. Based on these behavioral responses, Burrowing Owls may be classified as removal indeterminate and addition determinate egg-layers. These results are consistent with the behavior of Pied Flycatchers (Ficedula hypoleuca), which is also a species that is removal indeterminate and addition determinate (Kern et al. 2000). In addition to Burrowing Owls, there are two other species of owl that have been classified as indeterminate: Barn Owls (Tyto alba; Durant et al. 2004), and Snowy Owls (Bubo 


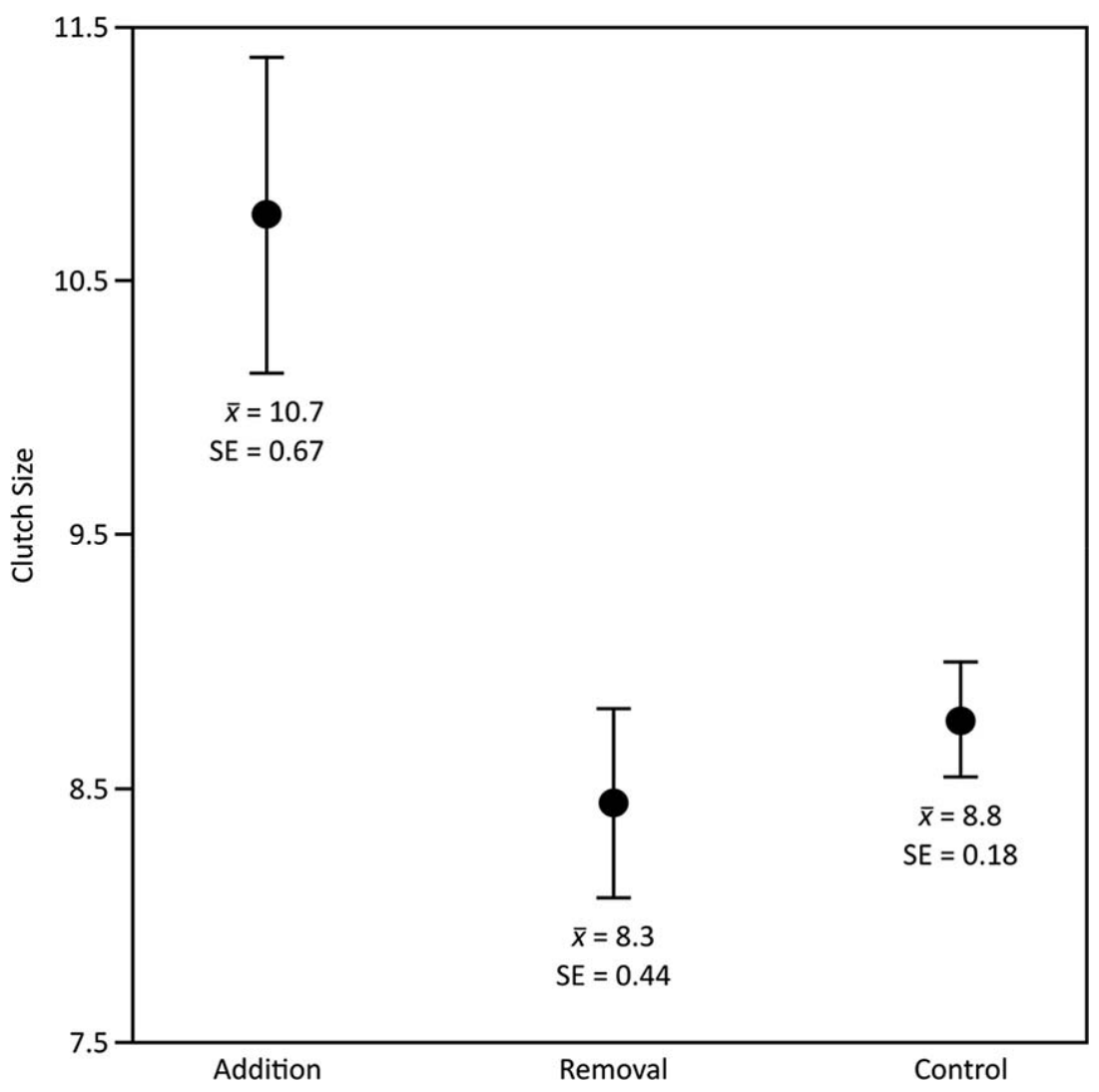

Figure 1. Mean \pm SE size of completed clutches at nests where one egg was added $(n=9)$ or removed $(n=9)$ during the laying period in relation to completed clutch sizes at control nests $(n=17)$ during the 2012 and 2013 breeding seasons in southwestern Idaho, U.S.A. Completed clutch sizes at addition nests include the egg that was added, whereas completed clutch sizes at removal nests does not include the egg that was removed.

scandiacus; Parmelee 1992). In a small study of captive-bred Barn Owls, Durant et al. (2004) found that females produced more ovarian follicles than eggs laid, and that the removal of the first and all subsequent eggs induced one female to lay 18 consecutive eggs (Y. Handrich unpubl. data cited in Durant et al. 2004). Snowy Owls demonstrate extreme flexibility in the number of eggs that they produce, which is largely attributed to the dramatic differences in annual food supply and environmental conditions (Parmelee 1992). As in Snowy Owls, food availability also affects clutch size in Barn Owls (Mikkola 1983, Taylor 1994). In contrast, supplemental feeding experiments showed that food abundance does not influence clutch size in Burrowing Owls (Wellicome et al. 2013).

Although it is not fully known when egg removal must occur for Burrowing Owls to respond in an indeterminate manner, our methods were efficacious in eliciting this response. We removed an egg from nests when females had laid 1-5 eggs. In some species, females will lay substantially more than one replacement egg, provided that the removals begin with the first egg laid (Brockway 1968, Gilbert et al. 1983, Rohwer 1984, Frumkin 1988, Arnold and Rohwer 1991). Eurasian Kestrel (Falco tinnunculus) females, for instance, lay additional eggs when their clutch size is reduced early in laying, but only if the removals are initiated before the females start spending half of their time incubating (Beukeboom et al. 1988, Meijer 1990). Often prolactin levels steadily increase as the female spends more time incubating, and thus prolactin may proximately regulate clutch size by suppressing the growth and development of additional ovarian follicles (Lea et al. 1981, El Halawani et al. 1984, Hall et al. 1986, Zadworny et al. 1989, Meijer 1990). Whether and to what extent prolactin influences clutch size, or what happens to 
prolactin concentrations throughout the egg-laying and incubation periods, is not known for Burrowing Owls.

Adaptive Benefits of Laying Patterns. There is still some debate as to why certain species of birds are determinate egg-layers and others are indeterminate egg-layers. For Burrowing Owls, an indeterminate response to egg removal could be an adaptive behavior that enables them to replace eggs that are lost as a result of predation or nest destruction. Nest predation in Burrowing Owls is one of the primary causes of nest failure (Green and Anthony 1989, Desmond et al. 2000, Moulton et al. 2006). Burrowing Owls may be particularly susceptible to nest predation because they nest belowground (Wellicome and Haug 1995, Sleno 2000). In north-central Oregon, predation was responsible for $20 \%$ of nest failures, and American badgers (Taxidea taxus) were responsible for $90 \%$ of those nests lost (Green and Anthony 1989). In other studies, the overall rate of nest predation can be higher (16-54\%; Desmond et al. 2000). In the case of a predation event, the ability to lay indeterminately would be beneficial especially if the loss of eggs occurs early in the laying period. This ability would allow female Burrowing Owls to replace any eggs that were lost or could help the female to quickly renest (Parsons 1976). Indeed, in a study of Burrowing Owl dispersal following experimental nest predation where entire clutches were removed after completion, Burrowing Owls rapidly renested and one female laid 29 eggs over four bouts of nesting (Catlin and Rosenberg 2008). For some bird species, renesting after predation can increase lifetime productivity (Martin et al. 1989, Hipfner 2001). Thus, given that predation is one of the primary causes of nest failure in Burrowing Owls, and that the results of our study indicate that Burrowing Owls replace an egg that is removed early in laying, removal indeterminate behavior likely provides Burrowing Owls with an avenue that allows them to produce a complete clutch following a loss of at least one egg from nest predation or other natural causes.

Similarly, indeterminate laying may be beneficial to nesting females who lose eggs during laying because they abandon or bury a partial clutch in response to brood parasitism. For example, if a nest is parasitized early in laying and the residents abandon or bury the corrupted clutch, which was a response of some female Burrowing Owls when exposed to experimental brood parasitism (see Groves 2014), an indeterminate female could avoid an unfavorable lag in egg-laying and instead produce a full complement of eggs without delay. Therefore, removal indeterminate behavior in Burrowing Owls could also be advantageous if their nest is parasitized (and later rejected) early in the laying cycle. Likewise, addition determinate behavior could also benefit females whose nests are parasitized. That is, females who are addition determinate would lay a full complement of their own eggs by not including the parasitic egg in their clutch size determination, and thus avoid the potential cost of a decreased genetic contribution to their own clutch.

Interestingly, indeterminate laying could also provide a fitness advantage for female Burrowing Owls that become brood parasites. For example, a female bird who parasitizes the nest of a conspecific, but also has a nest of her own, could avoid a potentially maladaptive clutch size reduction, provided that she is able to prolong laying (i.e., lay indeterminately) until she has a full complement of eggs in her own nest (Kendra et al. 1988). In contrast, a determinate egg-layer would be unable to avoid sacrificing clutch size in her own nest, as each egg she lays in another female's nest would result in one fewer egg in her own nest. Therefore, it is possible that indeterminate laying behavior in Burrowing Owls could benefit a female if she laid eggs in her own nest, but she also laid some eggs parasitically. The extent to which female Burrowing Owls engage in CBP is poorly understood, but Johnson (1997) and Groves (2014) discuss observations consistent with this possibility (see also Rodriguez-Martínez et al. 2014).

Conclusions. We altered clutch size of Burrowing Owls by removing or adding one egg during the laying period. Our findings suggest that Burrowing Owls are removal indeterminate and addition determinate egg-layers and therefore provide new understanding of Burrowing Owl reproductive behavior.

\section{ACKNOWLEDGMENTS}

We thank D. White, M. Knutsen, M. McCowin, G. Frye, N. Santiago, N. Brock, A. Renken, K. Riebe and others for assistance with fieldwork and J. Barber, I. Robertson, D. Rosenberg, and an anonymous reviewer for very helpful comments that improved our manuscript. Financial assistance was provided by Sigma Xi, The Scientific Research Society, and the following Boise State University entities: the Hemingway Western Studies Center, the Student Research Initiative, the Raptor Research Center, and the Department of Biological Sciences. J. Wade was also supported by a GK-12 Teaching Fellowship from the National Science Foundation (Award Number DBI 0742554 to K. Viskupic, J. Belthoff, and D. Wilkins) during portions of this 
research. Boise State University's Institutional Animal Care and Use Committee approved the procedures employed in this research (Approval \#006-AC12-004), and scientific permits authorizing the work were in place from both state and federal agencies.

\section{Literature Cited}

Arnold, T.W. And F.C. Rohwer. 1991. Do egg formation costs limit clutch size in waterfowl? A skeptical view. Condor 93:1032-1038.

Belthoff, J.R. And B.W. SMith. 2003. Patterns of artificial burrow occupancy and reuse by Burrowing Owls in Idaho. Wildlife Society Bulletin 31:138-144.

Beukeboom, L., C. Dijkstra, S. DaAn, and T. MejJer. 1988. Seasonality of clutch size determination in the kestrel Falco tinnunculus: an experimental approach. Ornis Scandinavica 19:41-48.

Boyce, M.S. and C.M. Perrins. 1987. Optimizing Great Tit clutch size in a fluctuating environment. Ecology 68:142-153.

BROCKWAY, B.F. 1968. Budgerigars are not determinate egglayers. Wilson Bulletin 80:106-107.

Catlin, D.H. And D.K. RosenberG. 2008. Breeding dispersal and nesting behavior of Burrowing Owls following experimental nest predation. American Midland Naturalist 159:1-7.

Charnov, E.L. And J.R. Krebs. 1974. On clutch size and fitness. Ibis 116:217-219.

Cole, L.J. 1917. Determinate and indeterminate laying cycles in birds. Anatomical Record 11:504-505.

. 1930. The laying cycle in the House Wren. Wilson Bulletin 42:78.

Conway, M., C.P. Nadeau, and C.J. Conway. 2012. Intraspecific variation in reproductive traits of Burrowing Owls. Journal of Ethology 30:395-402.

Desmond, M.J., J.A. SAVIdGe, And K.M. Eskridge. 2000. Correlations between Burrowing Owl and black-tailed prairie dog declines: a 7-year analysis. Journal of Wildlife Management 64:1067-1075.

Durant, J.M., S. Massemin, and Y. Handrich. 2004. More eggs the better: egg formation in captive Barn Owls (Tyto alba). Auk 121:103-109.

El Halawani, M.E., W.H. Burke, J.R. Millam, S.C. Fehrer, AND B.M. HARGIS. 1984. Regulation of prolactin and its role in Gallinaceous bird reproduction. Journal of Experimental Zoology 232:521-529.

FrumkIn, R. 1988. Egg quality breeding and dispersal in sparrowhawks. Ph.D. dissertation. Oxford Univ., Oxford, U.K.

Gilbert, A.B., M.M. Perry, D. Waddington, and M.A. HARDIE. 1983. Role of atresia in establishing the follicular hierarchy in the ovary of the domestic hen (Gallus domesticus). Journal of Reproduction and Fertility 69: 221-227.

Green, G.A. And R.G. AnThOny. 1989. Nesting success and habitat relationships of Burrowing Owls in the Columbia Basin, Oregon. Condor 91:347-354.
GROvEs, J.L. 2014. Behavioral responses of Burrowing Owls to experimental clutch manipulations: an investigation of conspecific brood parasitism and laying determinacy. M.S. thesis, Boise State Univ., Boise, ID U.S.A.

HAFTORN, S. 1985. Variation in clutch size and egg dimensions of the Great Tit Parus major. Fauna Norvegica Series C, Cinclus 8:106-115.

Hall, T.R., S. Harvey, and A. Chadwick. 1986. Control of prolactin secretion in birds: a review. General and Comparative Endocrinology 62:171-184.

HaYwOod, S. 1993. Sensory and hormonal control of clutch size in birds. Quarterly Review of Biology 68:33-60.

. 2013. Origin of evolutionary change in avian clutch size. Biological Reviews 88:895-911.

HiPfNER, J.M. 2001. Fitness-related consequences of relaying in an Arctic seabird: survival of offspring to recruitment age. Auk 118:1076-1080.

Hironaka, M., M.A. Fosberg, and A.H. WinWard. 1983. Sagebrush-grass habitat types of southern Idaho. Forest, Wildlife and Range Experiment Station, University of Idaho, Bulletin 35, Moscow, ID U.S.A.

Hogstedt, G. 1980. Evolution of clutch size in birds: adaptive variation in relation to territory quality. Science 210:1148-1150.

Holcomb, L.C. 1971. Nest building and egg laying by Redwinged Blackbirds in response to artificial manipulations. Auk 88:30-34.

INGRAM, C. 1959. The importance of juvenile cannibalism in the breeding biology of certain birds of prey. Auk 76:218-226.

JoHnSON, B.S. 1997. Reproductive success, relatedness, and mating patterns of colonial Burrowing Owls. Pages 64 67 in J.L. Lincer and K. Steenhof [EDS.], The Burrowing Owl, its biology and management: including the proceedings of the First International Burrowing Owl Symposium. Raptor Research Report 9.

Kendra, P.E., R.R. Roth, and D.W. Tallamy. 1988. Conspecific brood parasitism in the House Sparrow. Wilson Bulletin 100:80-90.

KenNEDy, E.D. 1991. Determinate and indeterminate egglaying patterns: a review. Condor 93:106-124.

— AND H.W. Power. 1990. Experiments on indeterminate laying in House Wrens and European Starlings. Condor 92:861-865.

KERN, M.D., R.J. COWIE, AND F.M. SLATER. 2000. Responses of egg-laying Pied Flycatchers to experimental changes in clutch size: a re-examination. Condor 102:428-432.

KLOMP, H. 1970. The determination of clutch-size in birds: a review. Ardea 58:1-124.

LACK, D. 1947. The significance of clutch-size. Ibis 89:302-352.

. 1954. The natural regulation of animal numbers. Clarendon Press, Oxford, U.K.

. 1966. Population studies of birds. Clarendon Press, Oxford, U.K.

AND E. LACK. 1951. The breeding biology of the Swift Apus apus. Ibis 93:501-546. 
LeA, R.W., A.S.M. Dods, P.J. Sharp, And A. ChadWick. 1981. The possible role of prolactin in the regulation of nesting behaviour and the secretion of luteinizing hormone in broody bantams. Journal of Endocrinology 91:89-97.

Martin, K., S.J. Hannon, and R.F. Rockwell. 1989. Clutch size variation and patterns of attrition in fecundity of Willow Ptarmigan. Ecology 70:1788-1799.

MeIJER, T. 1990. Incubation development and clutch size in the starling. Ornis Scandinavica 21:163-168.

Mikkola, H. 1983. Owls of Europe. Poyser, Carlton, London, U.K.

Moulton, C.E., R.S. Brady, And J.R. Belthoff. 2006. Association between wildlife and agriculture: underlying mechanisms and implications in Burrowing Owls. Journal of Wildlife Management 70:708-716.

Nur, N. 1986. Is clutch size variation in the Blue Tit (Parus caeruleus) adaptive? An experimental study. Journal of Animal Ecology 55:983-999.

OlEnICK, B.E. 1990. Breeding biology of Burrowing Owls using artificial nest burrows in southeastern Idaho. M.S. thesis, Idaho State Univ., Pocatello, ID U.S.A.

Parmelee, D.F. 1992. Snowy Owl (Nyctea scandiaca). In A. Poole, P. Stettenheim, and F. Gill [EDS.], The birds of North America, No. 10. The Academy of Natural Sciences, Philadelphia, PA and the American Ornithologists' Union, Washington, DC U.S.A.

PARSONS, J. 1976. Factors determining the number and size of eggs laid by the Herring Gull. Condor 78: 481-492.

Perrins, C.M. 1965. Population fluctuations and clutch-size in the Great Tit, Parus major L. Journal of Animal Ecology 34:601-647.

AND D. Moss. 1975. Reproductive rates in the Great Tit. Journal of Animal Ecology 44:695-706.

Pettifor, R.A., C.M. Perrins, and R.H. McCleery. 1988. Individual optimization of clutch size in Great Tits. Nature 336:160-162.

Poulin, R., L.D. Todd, E.A. Haug, B.A. Millsap, and M.S. MARTEll. 2011. Burrowing Owl (Athene cunicularia). In A. Poole [ED.], The birds of North America online, No. 61. Cornell Lab of Ornithology, Ithaca, NY U.S.A. http://bna.birds.cornell.edu/bna/species/061 (last accessed 24 September 2015).
Rodriguez-Martínez, S., M. Carrete, S. Roques, N. ReboloIFRAN, AND J.L. TELLA. 2014. High urban breeding densities do not disrupt genetic monogamy in a bird species. PLoS One 9: e91314. doi:10.1371/journal.pone.0091314.

RoHwer, F.C. 1984. Patterns of egg laying in prairie ducks. Auk 101:603-605.

SLenO, J. 2000. Possible cat predation on Burrowing Owls. Blue Jay 58:191-192.

Smith, B.W. ANd J.R. Belthoff. 2001. Effects of nest dimensions on use of artificial burrow systems by Burrowing Owls. Journal of Wildlife Management 65:318-326.

STEARns, S.C. 1976. Life-history tactics: a review of the ideas. Quarterly Review of Biology 51:3-47.

TAYLOR, I.R. 1994. Barn Owls: predator-prey relationships and conservation. Cambridge University Press, Cambridge, U.K.

Thomson, D.L., P. Monaghan, and R.W. Furness. 1998. The demands of incubation and avian clutch size. Biological Reviews of the Cambridge Philosophical Society 73:293-304.

U.S. DEPARTMENT OF THE INTERIOR (U.S.D.I.). 1996. Effects of military training and fire in the Snake River Birds of Prey National Conservation Area. BLM/IDARNG research project final report. U.S. Geological Survey, Biological Research Division, Snake River Field Station, Boise, ID U.S.A.

Wellicome, T.I. ANd E.A. Haug. 1995. Second update of status report on the Burrowing Owl (Speotyto cunicularia) in Canada. Committee on the Status of Endangered Wildlife in Canada, Ottawa, ON Canada.

- L.D. Todd, R.G. Poulin, G.L. Holroyd, AND R.J. FisHeR. 2013. Comparing food limitation among three stages of nesting: supplementation experiments with the Burrowing Owl. Ecology and Evolution 3: 2684-2695.

WiLliams, G.C. 1966. Natural selection, the costs of reproduction, and a refinement of Lack's principle. American Naturalist 100:687-690.

Zadworny, D., K. ShimadA, H. IshidA, AND K. SATO. 1989. Gonadotropin-stimulated estradiol production in small ovarian follicles of the hen is suppressed by physiological concentrations of prolactin in vitro. General and Comparative Endocrinology 74:468-473.

Received 26 January 2015; accepted 17 August 2015 